\title{
Deposit of Compensation in Land Acquisition for the Construction of the Padang- Pekanbaru Toll Road in Public Interest
}

\author{
Debby Khristina ${ }^{1}$; Kurnia Warman ${ }^{2}$; Hengki Andora ${ }^{2}$ \\ ${ }^{1}$ Master of Law Science, Faculty of Law, Andalas University, Indonesia \\ ${ }^{2}$ Faculty of Law, Andalas University, Indonesia \\ http://dx.doi.org/10.18415/ijmmu.v7i8.1877
}

\begin{abstract}
Deposit of compensation at the Court which is carried out in land acquisition for the public interest is one of the solutions to accelerate the development process. The disagreement of the parties regarding compensation has made the agency managing the project use a consignment mechanism to solve this compensation problem. Therefore, this research is focused on 3 (three) main problems. First, what is the process of assessing and determining compensation for land acquisition for the construction of the Padang-Pekanbaru toll road on Jalan Padang-Sicincin? Second, what is the process of filing an objection to the determination of the form and / or amount of compensation at the Pariaman District Court? Third, how is the implementation of deposit for compensation in land acquisition for the construction of the Padang-Pekanbaru toll road on the Padang-Sicincin road? This type of research is empirical juridical legal research and to answer the above problems, this study uses primary data and secondary data. Primary data is obtained through field research, while secondary data is obtained from tracing laws and regulations and decisions of Constitutional Court judges. The data analysis was conducted in a descriptive qualitative manner. The results showed that the process of appraising and determining compensation for land acquisition was carried out starting from the process of appointing the appraisal team, the assessment of compensation by the appraisal team, deliberation, and the process of determining the compensation. The appointment of an appraisal team is determined by the Chief Executive of Land Acquisition using the direct procurement method. The appraiser makes an appraisal using the Fair Replacement Value and refers to the SPI 306 Technical Guidelines. The results of the appraisal are used as the basis for deliberations to determine compensation. The fact is that the deliberations are carried out as it should be, but the price set by the Appraiser (Appraisal) is as if only a final price that must be agreed upon by the entitled Party, even though the price recommended by the Appraisal is a price that is the price for negotiating with the community land owner. The process for filing an objection to the determination of the form and / or amount of compensation at the Pariaman District Court is in accordance with the Supreme Court Regulation No.3 of 2016 and is a form of legal protection for land rights owners. The implementation of land's deposit compensation at the Pariaman District Court is carried out in accordance with the Supreme Court Regulation Number 3 of 2016 and in the Compensation of the Damages awaits a court process that has permanent legal force so that the money can be given to the party entitled to receive it.
\end{abstract}

Keywords: Deposition of Compensation; Land Acquisition; Public Interest 


\section{Introduction}

Land is closely related to community behavior so that nowadays people are competing to control and own the land they want because it has economic value for all aspects of life. Land in the Law Dictionary is defined as the surface of the earth or the layer of the earth which is above once, the state of the earth in a place, the surface of the earth which is bounded, land. ${ }^{1}$ So, land is the residence of families and communities that provide livelihoods, is also a place where residents who die and are buried according to their beliefs and are also the residence of the guardian gods and where the spirits of the ancestors reside. ${ }^{2}$ In addition, land is a means for farming and raising livestock as well as for cultivation, even land is a property that can be inherited for children and grandchildren. The importance of land for human life makes it a legal issue where rights arise in relation to buildings or objects on the land.

In Boedi Harsono's book, the principle of land law adhered to by the State of Malaysia, Singapore and others is the principle of accessie or the principle of "attachment" which means that the building and objects / plants contained therein are an integral part of the land and are part of the land concerned so that which includes the definition of land rights includes ownership of buildings and plants on land that is recognized unless there is another agreement with the party who built or planted it (Civil Code Articles 500 and 571). ${ }^{3}$ In contrast to the Indonesian Land Law which adheres to the principle of "Customary Law", namely "the principle of horizontal separation" in Dutch it is called "horizontale scheiding" which means that buildings and plants are not part of the land concerned so that land rights do not necessarily include ownership of buildings. and the plants on it, as well as the legal actions of the land do not necessarily belong to the owner of the land but must be proven by a deed. ${ }^{4}$ From this principle, it can be concluded that legal actions can be carried out on the land alone or on buildings and / or plants alone or it can also be against the land as well as the buildings and perennials on it. It is possible that in one plot of land there are several ownership of the land simultaneously, for example in one plot of land it can be different between the owner of the land, the owner of the coconut, the owner of the rice field or the person who works the rice field. From the description above, it can be seen that land has tremendous influence and benefits in human life as well as land which is the glue of the Unitary State of the Republic of Indonesia and therefore needs to be regulated and managed nationally to maintain the sustainability of the life system of the nation and state. ${ }^{5}$

As explained in the 1945 Constitution which has provided a legal basis that there is a legal relationship between the state and land which ultimately gives birth to land rights by the state as in Article 33 paragraph (3) of the 1945 Constitution which states that the land and land water and natural resources contained therein shall be controlled by the state and used maximally for the prosperity of the people. From these basic provisions, it can be seen that the prosperity of the community is the main objective in exploiting the natural wealth contained therein. Indonesian society whose economy is still in an agrarian style and agrarian law was still influenced by the colonial government so that it was against the interests

\footnotetext{
1 Sudarsono, Legal Dictionary, Rineka Cipta, Jakarta, 2012, p. 483.

2 Supriadi, Agrarian Law, Sinar Grafika, Jakarta, 2016, p. 15.

${ }^{3}$ Boedi Harsono, Indonesian Agrarian Law, History of the Formation of Basic Agrarian Laws, Content and Implementation, Volume I of National Land Law, Trisakti University, Jakarta, 2016, p. 20. In article 500 of the Civil Code states that everything that is due to the law of attachment is included in a material thing, like all the results of that material, whether it is the result of nature or the result of people's work, as long as what is recently attached to the material is like branches and roots attached to the soil, all of which are part of the material. Article 571 of the Civil Code states that the right to own a plot of land contains in it, ownership of everything on it and in the land. On the land, it is permissible for the owner to cultivate all the plants and build any building he likes, without prejudice to some of the exceptions mentioned in the fourth and sixth chapters of this book (KUHPerdt). Under the ground, it is permissible for him to make and dig at will and have all the results obtained because of the excavation, without prejudice to the changes that must be carried out in connection with laws and government regulations regarding mining, coal extraction, buried garbage and so on.

${ }^{4}$ Ibid.

${ }^{5}$ Ibid., p. LIX.
} 
of the people and the state in completing the national revolution so that it was the background for the birth of Law Number 5 of 1960 concerning Basic Basic Agrarian Regulations (UUPA).

This law was ratified by President Soekarno on September 24, 1960 and promulgated in State Gazette Number 104 of 1960 and the explanation was contained in the Supplement to the State Gazette of the Republic of Indonesia Number 2043, and better known as the Basic Agrarian Law hereinafter referred to as UUPA which is one a very important milestone in the history of agrarian or land development in Indonesia in general and the reform of Indonesian Agrarian Law or Land Law in particular. ${ }^{6}$ In this UUPA there is a principle of State control rights over land contained in Article 2 paragraph (1) which states that: "Earth, water and space including natural resources in them are at the highest level controlled by the State, as an organization of power for all the people". ${ }^{7}$ Through the right to control of the State, the State as the governing body will always be able to control or direct the management of the functions of the earth, water and space and the natural resources contained therein in accordance with existing regulations and policies, namely within the scope of juridical control which has a public aspect where All objects provided to carry out public interests are state assets in the form of public property as seen from the way the government leaves them open to the public. ${ }^{8}$

In line with the times, the Government continues to strive for development for the public interest in order to improve the people's welfare, in the sense of happiness and the creation of a harmonious life order in society and an Indonesian constitutional state that is independent, sovereign, just and prosperous. In order to achieve this, the Government needs land which is used to support the main tasks of the government. Land controlled by the government is a means for building various kinds of infrastructure, either directly used for the purposes of administering government affairs or for building various facilities that can be enjoyed and utilized jointly by members of the community. ${ }^{9}$ One of the government legal instruments for obtaining the land is by carrying out land acquisition in development which is used to fulfill the need for land in the public interest. In this regard, in order to realize the noble ideals of the Indonesian nation, the Government uses this legal instrument to build public facilities such as toll roads, reservoirs or power plants, government offices, hospitals, terminals, markets, airports, and so on. others, all of which require soil as a container.

In the UUPA it is stated in Article 4 that on the basis of the right to control from the state as meant in Article 2, it is determined that there are various rights to the surface of the earth, which are called land, which can be given to or owned by people, either individually or collectively, other people as well as legal entities. Mudakir Iskandarsyah also stated that the state's power to control the land is based on the application of social functions to land. ${ }^{10}$ Social function here means that the use of the land is prioritized for the public interest rather than for the interests of individuals or groups, but because the community is still common with the social meaning and function of land, it causes the community to consider land ownership to be absolute and inviolable by anyone, including the State, even though the State is in this case having rights to the land is known as the right to control. ${ }^{11}$ So that the state has the authority to regulate the use of land for the welfare of the community. In addition, Maria SW Sumardjono

\footnotetext{
6 Ibid., p. 1.

${ }^{7}$ Law of the Republic of Indonesia Number 5 of 1960 concerning Basic Agrarian Principles, State Gazette of the Republic of Indonesia of 1960 Number 104, Supplement to State Gazette of the Republic of Indonesia Number 2043, Article 2.

${ }^{8}$ E. Utrecht, Philipus M.Hadjon, (in Hengki Andora's Dissertation, (Land Control and Management by Government Agencies (Interaction of Land Law and State Financial Law in the Indonesian Legal System, Dissertation, Doctor of Law Program at Gadjah Mada University, 2019)).

9 Ibid., p.3.

${ }^{10}$ Mudakir Iskandar Syah, Land Acquisition for Public Interest Development, Permata Aksara, Jakarta, 2015, p. 7.

11 Ibid., p. 6.
} 
also argues that this social function sometimes requires that private interests in land be sacrificed for the sake of public interest. ${ }^{12}$

The social function in the conception of the National Land Law and the conception of the UUPA states that the nature of individual rights to land has a collective or social nature so that land use must be adjusted to the circumstances and nature of its rights which will benefit both the welfare and happiness of the land owner and the community and country. This also implies that the individual as well as a social being must strive for the realization of a balance, harmony and harmony between personal interests and common interests as well as the interests of the community. This is in line with the content of Article 6 of the UUPA which states that all land rights have a social function, which means that land rights that belong to a person cannot be justified if the land rights are misused and must be endeavored so that the land is beneficial for the right holders who have volunteered, sacrifice their land, as well as for the community by taking into account individual interests that are recognized and respected in the context of implementing the interests of the community. ${ }^{13}$

To reach an agreement according to what the community wants is very difficult, so that for the sake of implementing Development for the public interest, the Government takes a solution by taking right lands. Therefore, Law Number 20 Year 1961 concerning Revocation of Rights to Land and Objects on it is used. The state can revoke land rights by providing appropriate compensation if deliberations conducted together with the community fail to bring results. According to Mudakir Iskandar, revocation must be preceded by deliberation at the initial stage of the land acquisition process and if the process of revocation of rights is not preceded by deliberation, then the revocation of land rights is considered legally flawed and can be prosecuted against the government. ${ }^{14}$ In fact, the substance of the issue of deprivation of ownership of land rights is related to human rights issues as contained in Law Number 39 of 1999 concerning Human Rights, where it is not justified to take one's land rights by other parties, let alone forcibly ignoring the aspirations of the holder. rights to the land it self. This is also contained in Article $28 \mathrm{H}$ paragraph (4) of the Second Amendment of the 1945 Constitution which states that "every person has the right to have private property rights and these property rights cannot be taken over arbitrarily by anyone".

Furthermore, in Article 1 paragraph 2 of Presidential Regulation Number 148 of 2015 concerning the fourth Amendment to Presidential Regulation Number 71 of 2012 concerning Implementation of Land Acquisition for Development for Public Interest, it is stated that "land acquisition is the activity of providing land by means of providing appropriate and fair compensation to entitled parties "where the party who controls or owns the object of land acquisition in the form of land, space above land and underground, or others that can be valued. ${ }^{15}$ This means that the revoked land rights will be compensated in the form of compensation. In the UUPA itself provides a legal basis for taking land rights, as regulated in Article 18, namely "For the public interest, including the interests of the Nation and the State as well as the common interests of the people, land rights can be revoked, by providing appropriate compensation and according to the way which is regulated by Law ".

In the event that the state land supply is still large, perhaps development for the sake of public interest will not meet any problems, but the problem is that land is a natural resource which is limited in nature and never increases in size. Many of the available lands are attached with hak (land rights), and state land is also very limited in supply. Development carried out by the government often collides with

\footnotetext{
${ }^{12}$ Maria SW Sumardjono, State Authority to Regulate in the Concept of State Ownership of Land, Gajah Mada University Press, Yogyakarta, 1998, p. 27.

${ }^{13}$ Lieke Lianadevi Tukgali, Social Function of Land Rights in Land Acquisition for Public Interest, Kertasputih Communication, Jakarta, 2010, p. 166.

${ }^{14}$ Mudakir Iskandarsyah, Basics of Land Acquisition for Public Interest, Jala Permata, Jakarta, 2007, p. 7.

${ }^{15}$ Presidential Regulation Number 148 of 2015 concerning the fourth Amendment to Presidential Regulation Number 71 of 2012 concerning Implementation of Land Acquisition for Development for Public Interest.
} 
various land acquisition problems that neglect the rights to land owned by the community. These problems arise both in the early stages of implementation and in the stage of providing inadequate compensation and without involving the community who hold land rights so that land acquisition arguing for the public interest often violates human rights. ${ }^{16}$ Individual rights owned by the community to land are included in the classification of economic rights or property rights, namely the right to own something, buy and sell it and use it. ${ }^{17}$

In empirical reality, it must be admitted that the implementation of land acquisition in the field always has problems, namely the difficulty of determining the value of compensation, the reason is that the land owner or land rights holder demands a very high price that exceeds the market price and the tax object selling value (NJOP). Then there are land brokers, namely people who become intermediaries and provide services to arrange something based on wages or commonly called land brokers, both from the community and from unscrupulous officials, and the limited government budget, in this case the land acquisition committee, often triggers conflicts between the government and the community. holders of land rights triggered by differences in demand for compensation prices. ${ }^{18}$ It can be seen that compensation is not the same as buying and selling, but in order for the compensation to be called fair, a guideline should be held that the provision of compensation must not make someone richer or otherwise poorer than before. ${ }^{19}$ For this reason, a serious commitment is needed to provide a fair basis and not to harm the community, so that there is a balance between the interests of the Government and the needs of the community in terms of land acquisition.

With the passage of Law Number 2 of 2012 concerning Land Acquisition for Development in the Public Interest as a progressive effort or progress made by lawmakers to regulate that compensation must be appropriate and fair, it is hoped that it can improve the implementation of land acquisition. Then for the Implementation Regulation Presidential Regulation Number 71 of 2012 concerning Implementation of Land Acquisition for Development for Public Interest has been amended several times by Presidential Regulation Number 40 of 2014, then by Presidential Regulation Number 99 of 2014, then Presidential Regulation Number 30 of 2015 and then finally with Presidential Regulation Number 148 of 2015 concerning the Fourth Amendment to Presidential Regulation Number 71 of 2012 concerning Implementation of Land Acquisition for Development for Public Interest. To implement this Presidential Regulation, the Head of the National Land Agency Regulation Number 5 of 2012 concerning Technical Guidelines for Land Acquisition was made amended by the Regulation of the Minister of Agrarian Affairs and Spatial Planning / Head of the National Land Agency Number 22 of 2015 concerning the Second Amendment to the Regulation of the Head of the National Land Agency Number 5 of 2012 concerning Technical Guidelines for Land Acquisition Implementation.

The land policy is always directed at increasing the use and use of land in a fair, transparent and productive manner by prioritizing the rights of the people and based on a harmonious and balanced spatial layout within the corridors of applicable laws and regulations based on an accountable public administration that can be accounted for. ${ }^{20}$ All of the above regulations are expected to become a legal basis in improving the implementation of land acquisition for development in Indonesia and can be implemented as well as possible. This determines that land acquisition for the implementation of development for the public interest carried out by the government in terms of providing compensation is carried out simultaneously with the release of rights by the entitled parties, while land acquisition for the implementation of development for the public interest carried out by a private business entity is carried

\footnotetext{
${ }^{16}$ Sri Haryono et al, "The Position of Land Rights in Land Acquisition for Development for Public Interest (Analysis of the Substance of Law No.2 of 2012 concerning Land Acquisition for Development for Public Interest)", January-June 2016, Faculty of Law, UNS, in the journal Repertorium Volume III No. 1, p. 93.

17 C.S.T. Kansil, About Human Rights Today, Unipres Work, Jakarta, 2003, p. 13.

18 Mustofa and Suratman, Use of Land Rights for Industry, Sinar Grafika, Jakarta, 2013, p. 183.

19 Maria S.W. Sumardjono, Land in the Perspective of Economic, Social and Cultural Rights, Kompas, Jakarta, 2008 , p. 251.

${ }^{20}$ Adrian Sutedi, Transfer of Land Rights and Registration, Sinar Grafika, Jakarta, 2017, p. 24.
} 
out by way of selling, purchase, exchange or other means agreed upon by the entitled parties with a private business entity. ${ }^{21}$

In this regard there are universal basic principles in land expropriation by the state as written in the article by Damang Averroes Al-Khawarizmi that "no private property shall be taken for public use without just and fair compensation". ${ }^{22}$ The meaning is that the expropriation process is carried out with fair and fair compensation. However, this principle is often neglected in practice. In this case, land acquisition that is carried out should prioritize the principles contained in the 1945 Constitution of the Republic of Indonesia and the national land law, including the principles of humanity, justice, benefit, certainty, openness, agreement, participation, welfare, sustainability, and harmony in accordance with the values of the nation and state. ${ }^{23}$ This is also in line with Article 2 of Law Number 2 of 2012 concerning Land Acquisition for Development for Public Interest which states that Land Acquisition for Public Interest is carried out based on the principles, namely : ${ }^{24}$

a. Humanitarian Principles, namely the principle in land acquisition must provide protection and respect for human rights, dignity and proportion of every citizen and population of Indonesia;

b. The principle of justice, is the principle that guarantees the rightful compensation to the party entitled to the land acquisition process so that they get the opportunity to lead a better life;

c. Benefit Principle, is the result of land acquisition capable of providing broad benefits for the interests of the community, nation and state;

d. The principle of certainty, which means to provide legal certainty for the availability of land in the process of land acquisition for development and to provide guarantees to the entitled party to obtain adequate compensation;

e. The principle of openness, is land acquisition for development carried out by providing access to the community to obtain information related to land acquisition;

f. Agreement Principle, is the land acquisition process carried out by deliberation of the parties without coercion to obtain a mutual agreement;

g. Principle of Participation, is support in the implementation of land acquisition through community participation, either directly or indirectly, from planning to development activities;

h. The principle of Welfare, namely land acquisition for development can provide added value for the survival of the entitled parties and society at large;

i. Principle of Sustainability, is a development activity that can take place continuously, continuously, to achieve the expected goals; and

j. The principle of harmony means that land acquisition for development can be balanced and in line with the interests of the community and the state.

Furthermore, the implementation of land acquisition for the public interest is regulated in Article 13 of Law Number 2 of 2012 through the stages of planning, preparation, implementation and submission of results. Agencies requiring land can propose the implementation of land acquisition to the land agency including inventory and identification of control, ownership, use and utilization of land, assessment of compensation, deliberations on determining compensation, provision of compensation, and release of agency land. ${ }^{25}$

\footnotetext{
21 Presidential Regulation Number 148 of 2015 concerning the fourth amendment to Presidential Regulation Number 71 of 2012 concerning Implementation of Land Acquisition for Development for Public Interest (Article 121 A).

${ }^{22}$ Negara Hukum,https://www.negarahukum.com/hukum/prinsip-prinsip-pengadaan-tanah-untuk-kepentingan-umum.html, accessed on 12 December 2019 at 06.00 WIB.

${ }^{23}$ Djoni Sumardi Gozali, Land Acquisition Law, UII Press Yogyakarta, Yogyakarta, 2018, p. 58.

${ }^{24}$ See the Elucidation of Law Number 2 of 2012 concerning Land Acquisition for Development for Public Interest.

${ }^{25}$ See Law no. 12 of 2012 concerning Land Acquisition for Development for Public Interest, Article 27 which regulates the Implementation of Land Acquisition.
} 
Land acquisition for public purposes which will be discussed in this article is the construction of the Padang-Pekanbaru toll road on the Padang-Sicincin road section which is the first toll road development in West Sumatra. Toll road is one of the public facilities that is part of the road network system and as a national road where the toll road is required to be used. TOL is an abbreviation of the phrase "Tax On Location" which means that every motorist using a certain road will be charged a fee on the spot when passing it. ${ }^{26}$ In Indonesia, a toll road is also called a freeway, which is a road that is devoted to two or more axle vehicles (cars, buses, trucks) and aims to shorten the distance and travel time from one place to another and tariff determination is based on the vehicle class. ${ }^{27}$ The construction of this toll road is one of the National Strategic Projects and as part of the Trans Sumatra toll road that connects Padang with Pekanbaru along 254.8 kilometers and is still constrained by land acquisition problems. ${ }^{28}$

In the Padang-Sicincin Section (section I), the construction of the first Pole Piling Section for the Padang-Pekanbaru toll road project was carried out in February 2018 until now it has been running for almost 2 (two) years and is still in the construction stage but the problem of land acquisition is due to problems. price or compensation and ownership disputes are the main reasons why the construction of this toll road is running slowly. In this land acquisition, people who hold land rights are given compensation in the form of compensation money which is useful for them to continue their life and achieve socio-economic welfare after their land is released. Regarding land acquisition for development purposes, there will always be a sense of dissatisfaction among people whose land rights are affected by the project, including in the construction of the Padang-Pekanbaru toll road. In the event that there are differences in the determination of compensation or compensation that prevent the parties from reaching a consensus, that is where the problem arises, on the one hand the land rights holder feels aggrieved, and on the other, the agency requiring land states that the budget requested by the community is not according to what has been assessed by the appraisal team or the independent assessment team.

Therefore, after going through the stages of deliberation to reach a consensus that has not been reached and has not brought results, the way to solve this problem is by depositing compensation to the local District Court which is also known as consignment. The use of consignment in Indonesia has also been applied in various regional developments, for example from land acquisition for the Semarang-Solo toll road project in Semarang Regency which ended with depositing compensation through the Semarang Regency District Court, construction of section 2 of the Cinere-Jagorawi (Cijago) toll road whose consignment entrusted to the Depok District Court, the Bogor-Ciawi-Sukabumi (Bocimi) toll road project, the Medan-Binjai toll road and others. Meanwhile, the use of consignment for the West Sumatra region was carried out in the land acquisition of the Duku-Minangkabau International Airport (BIM) railbus construction project which ended with the deposit of compensation at the Pariaman District Court, the Batang Maransi-Batang Luruih flood control route project, whose consignment was at the District Court Padang, and what is being discussed in this article is the construction of the Padang-Pekanbaru toll road on the Padang-Sicincin road.

In the construction of the Padang-Pekanbaru toll road, the Padang-Sicincin road section, the problematic lands discussed were at the Station (STA $0+000$ to STA $4+200$ ) related to the price set by the appraisal team (independent appraisal team) at the Muttaqin Bambang Purwanto Rozak Uswatun and Rekan Public Appraisal Service Office (KJPP MBPRU) are considered by the community to be very low when compared to the Tax Object Acquisition Value (NPOP) in 2018. The community objected to giving their land because the government was deemed too small for compensation per one meter of land according to what had been determined by the appraisal team. This was felt by the community as

\footnotetext{
${ }^{26}$ Pramudyana Agus Harlianto, The Human Energy Company (toll road socialization videos), Pekanbaru-Dumai, 2020.

${ }^{27}$ Wikipedia; https://id.wikipedia.org/wiki/Jalan_tol, accessed on 9 December 2019, 14.00 WIB.

${ }^{28} \mathrm{CNN}$ Indonesia;https://www.cnnindonesia.com/ekonomi/20190617201255-92-404045/pemerintah-pastikan-tol-padangpekanbaru-tetap-dibangun, accessed on December 10, 2019 at 14.00 WIB.
} 
something that was far from fairness and justice so that the people who owned the land filed an objection to the Pariaman District Court as the holder of land rights.

Furthermore, the Pariaman District Court with decision Number 32 / Pdt.G / 2018 / PN-Pmn dated 31 July 2018 has rejected the lawsuit and declared the applicants' objections unacceptable or NO (Niet Ovankalijke Verklaard). Then on the Court's Decision, the Petitioners did not file a cassation action so that the Pariaman District Court Decision was inked and was a decision that had permanent legal force. Because the construction must be carried out immediately even though the owner of the land rights does not agree to the compensation, the agency of the project manager uses a consignment mechanism at the Pariaman District Court to resolve this compensation problem.

In this case the Government takes quick steps to carry out development in the name of the public interest. But in reality, the consignment carried out by the government / agency requiring land constitutes a forced expropriation of land or land and for those who disagree who have taken legal channels. Likewise in the implementation of compensation payments that have not been fully implemented but the land in question has been used and built for the public interest.

It can be seen that there are legal problems that arise as a result of this land acquisition which can disrupt the smooth running of development. The gap between das sollen as stated in the prevailing laws and regulations and das sein is a reality that occurs in the field. ${ }^{29}$ In connection with the description above, research related to land compensation was carried out in which this article was entitled "Deposit Of Compensation in Land Acquisition for the Construction of the Padang-Pekanbaru Toll Road in Public Interest".

Based on the description of the background of the problem, the research in this article will examine the problems including :

1. What is the process of assessing and determining compensation for land acquisition for the construction of the Padang-Pekanbaru toll road on the Padang-Sicincin road segment?

2. What is the process of submitting an objection to the determination of the form and / or amount of compensation at the Pariaman District Court?

3. How is the implementation of land's deposit compensation acquisition for the construction of the Padang-Pekanbaru toll road on the Padang-Sicincin road segment?

From the results of literature search, several other studies that approach the title of this article can be found, including :

1. Muhammad Fadli, a student of Master of Law Science at Andalas University in 2018, conducted a research entitled "Recognition of the Customary Rights of Customary Law Communities in Land Acquisition for Development on Former West Land Rights in West Sumatra". The research problems examined in his thesis are : ${ }^{30}$

a. Regarding how the customary rights in land acquisition for development for public interest on land that was formerly entitled to the west.

\footnotetext{
29 Maria S.W. Sumardjono, supra (see footnote 11), p. 100.

30 See Muhammad Fadli, Recognition of the Customary Rights of Customary Law Communities in Land Procurement for Development on Former West Land Rights in West Sumatra, Thesis, Master's Program in Law at Andalas University, Padang, 2018.
} 
b. Regarding how the recognition of customary rights in land acquisition for government development that is not a public interest on land that was formerly entitled to the west.

c. Regarding how the recognition of customary rights in land acquisition for development by private parties who are not in public interest on land that was formerly entitled to the west.

From the results of his research, Muhammad Fadli concluded that the recognition of customary rights in land acquisition for development for the public interest on land formerly western rights by the government experienced obstacles because it occurred due to the government's indecisiveness in planning and implementing land acquisition, compensation that was not prepared, and lack of customary recognition of customary land by the government. Then the development that is not for the public interest on land that is formerly a western right, there is no problem or conflict from the indigenous peoples but the problem that arises is not in the land of the erfpacht rights but from the customary land used in development not for the public interest.

Furthermore, Muhammad Fadli also conducted research on the company PT. Karya Agung Megah Utama, which tends to get land easily because it recognizes the existence of ulayat nagari land and the company also provides compensation to the customary law community of Nagari Lubuk Basung as a form of recognition of ulayat land owned by Nagari Lubuk Basung. ${ }^{31}$ The difference between this research and Muhammad Fadli's research lies in the focus of the research which specifically discusses the deposit of compensation in land acquisition for the construction of the Padang-Pekanbaru toll road.

2. Poppy Yulianti, a 2018 Andalas University Master of Law student with the title "Use of Consignment for Settlement of Compensation in Land Acquisition for Public Interest in West Sumatra". The discussion studied in his thesis is : ${ }^{32}$

a. Regarding how the consignment is used in the event that the party entitled to refuse the form and / or amount of compensation is unknown.

b. Regarding how the consignment is used in the event that the party entitled to receive compensation is not known where it is.

c. Regarding how to use a consignment in the event that the land acquisition object to be compensated is being the object of a case in court / ownership is still disputed / is confiscated by the authorized official / becomes collateral at the bank.

From the results of this research, Poppy Yulianti concluded that the use of consignment in the event that the party has the right to refuse the form and / or amount of compensation based on the results of deliberation in the case of disagreement with the compensation generated based on deliberation, there are parties who disagree but do not raise objections to the court, and there are also those who file objections to the court but still reject the compensation that has been determined based on the decision of the District Court / Supreme Court which has obtained permanent legal force.

Then in the event that the party entitled to receive compensation is unknown, the land acquisition implementer will deliver a notification regarding the absence of the entitled party in writing to the subdistrict and head of village / village head or other names, besides that it is also necessary to be notified through local, national and regional newspapers. other media. Then Poppy also argued that ignorance of the existence of the compensation recipient could lead to the deposition of the consignment money in the Registrar's treasury for an indefinite period of time because there are no laws and regulations and other implementing arrangements that regulate the deposit period for consignment money. In addition, it can cause ambiguity from not knowing the whereabouts of the compensation recipients, so that the court does not want to accept or return the files registered.

31 Ibid.

${ }^{32}$ See Poppy Yulianti, Use of Consignment to Settle Compensation in Land Acquisition for Public Interest, Thesis, Andalas University Master of Law Program, Padang, 2018. 
Furthermore, Poppy Yulianti also argues that the object of land acquisition to be compensated is being the object of a case in court or having its ownership disputed or being confiscated by an authorized official or a bank guarantee, in essence it is not a problem in practice, but problems will arise where the object is The land acquisition is still in a family dispute which has resulted in misinterpretation in court proceedings. The difference between this study and Poppy Yulianti's research lies in the subject, object of research and discussion of the problem. ${ }^{33}$

From the description above, the research in this article is a different study in the perspective of analyzing the problem, but if there is the same research without the author's knowledge, it is hoped that this research can complement the existing research results.

\section{Research Methods}

The nature of the research used in this research is juridical empirical legal research (socio legal research). Empirical juridical research is legal research regarding the enactment or implementation of normative legal provisions in action at any particular legal event that occurs in society. ${ }^{34}$ This research is descriptive analytical, namely research that aims to describe the state of something in a certain area and at a certain time by presenting detailed research results about the problems described above, as well as the obstacles faced and what legal measures can be taken to solve these problems. . The type of data in this study comes from primary data and secondary data. Primary data is data that comes from the field obtained from respondents, namely people or groups of people who provide answers to the questions posed by researchers, while secondary data in this study is data whose second level is not the main one.

\section{Results and Discussion}

\section{A. Overview of the Research Location}

Based on the Decree of the Governor of West Sumatra Number: 620-80-2018 dated 5 February 2018, the Location of Land Acquisition for the Construction of the Padang-Lubuk Alung-Padang Panjang-Bukittinggi Toll Road (Padang-Sicincin Section Sta $0+000$ to Sta $4+200$ ) was determined area $+35 \mathrm{Ha}$ (approximately thirty five hectares). The Padang - Pekanbaru Toll Road on the Padang-Sicincin Road Section is located in the Padang Pariaman Regency with the district capital being Parit Malintang which before that the capital was Kota Pariaman. The Padang-Pekanbaru Toll Road on the PadangSicincin road section is located along Kenagarian Kasang in Batang Anai District, which contains 109 (one hundred and nine) parcels of land belonging to the community with a distance of $0-4.2$ kilometers. ${ }^{35}$

\section{B. The Process of Appraisal and Determination of Compensation in Land Acquisition for the Construction of the Padang-Pekanbaru Toll Road on the Padang-Sicincin Road Section 1. Appraisal Team Appointment Process}

The appointment of an Appraiser or Public Appraiser in land acquisition for the Padang-Sicincin toll road is carried out in accordance with Article 63 of Presidential Regulation Number 99 of 2014 concerning Second Amendment to Presidential Regulation Number 71 of 2012 concerning Implementation of Land Acquisition for Development for Public Interest jo Article 20 Regulation of the Head of the National Land Agency Number 5 of 2012 concerning Technical Guidelines for Land Acquisition Implementation in which the Head of the Land Acquisition Office of Padang Pariaman

\footnotetext{
33 Ibid.

${ }^{34}$ Abdul Kadir Muhammad, Law and Legal Research, Citra Aditya Bhakti, Bandung, 2004, p. 134.

${ }^{35}$ Interview with the Head of Sub-Section for Land Acquisition at the District Land Office Padang Pariaman.
} 
Regency as the Head of Land Acquisition Implementation (KP2T) for the Padang-Pekanbaru toll road, determines the Land Acquisition Appraiser in accordance with the provisions of statutory regulations. invitation in the field of government procurement of goods / services. ${ }^{36}$ The method used is direct procurement, which is the method of selecting to obtain Consulting Service providers with the highest value of Rp. 500,000,000, - (five hundred million rupiah) in accordance with Presidential Regulation Number 3 of 2016 concerning Acceleration of Implementation of National Strategic Projects CHAPTER VIII Article 27 paragraph (2) letter a. ${ }^{37}$

Appraisers who are appointed and have obtained permission from the Minister of Finance and have obtained a license from the Ministry to calculate the value / price of the Land Acquisition object is the Public Appraisal Service Office Muttaqin Bambang Purwanto Rozak Uswatun \& Rekan, which is located in the City of Padang (hereinafter referred to as KJPP MBPRU) with a Decree Determination of Appraisal Services or Public Appraisers for Land Acquisition Activities for the Construction of the Padang-Lubuk Alung-Padang Panjang-Bukittinggi Toll Road, the Padang-Sicincin Section Sta $0+000$ to Sta $4+200$ with a land area of + 35 Ha, Number: 128 / KEP-13.05 / V / 2018 dated 9 May 2018 stipulated by the Head of the Land Office of Padang Pariaman Regency. Subsequently, a cooperation contract was carried out between the Minister of Public Works and Public Housing through the Commitment Officer for Land Acquisition for the Padang-Sicincin toll road at the Ministry of PUPR.

\section{The Assessment Process for Compensation by the Assessment Team}

With a Work Order Number: HK.02.03 / 015415 / CK-498 dated 11 May 2018, KJPP MBPRU is tasked with conducting an appraisal per plot of land to be compensated in accordance with the provisions under Article 1 point 4 of Law No. 2 of 2012 in conjunction with Article 1 number 4 of the Presidential Decree No. 71 of 2012 in conjunction with Article 3 of the Regulation of the Head of the National Land Agency No. 5 of 2012 includes:

1) Land;

2) Above ground and underground space;

3) Buildings;

4) Plants;

5) Objects related to land; and / or

6) Other assessable losses.

To carry out this task, KJPP MBPRU asks for a map of land parcels, a nominative list and data needed for assessment materials from the Head of Land Acquisition Implementation (P2T) and the Chairperson of P2T submits the requested data by making it in the Minutes of Submission of Inventory and Identification Results. After that the Appraiser performs technical data processing and observations ordered and against the nominative list such as number, name, owner, parcel (field), must be verified.

Then a field survey was conducted to see directly from the ground the object to be assessed. It can be seen, by referring to the improvement of the nominative list of land acquisition No. 03/2018 dated 9 May 2018, there is land that has been certified, whether the right holder is a mamak head of inheritance (customary land), there is also a certificate whose right holder is in a personal name, and there is also land that has not been certified. The appraiser's assessment is the value of compensation at the announcement of the determination of the construction location for the public interest. ${ }^{38}$

\footnotetext{
${ }^{36}$ Article 20 paragraph (1) Head of BPN Regulation No. 5 of 2012.

${ }^{37}$ Result of interview with Mr. M. Rofiud Rozak, Appraiser at KJPP MBPRU.

${ }^{38}$ Article 66 Presidential Regulation Number 71 of 2012.
} 
The basis for the assessment is carried out by KJPP MBPRU with Fair Replacement Value, namely the market value resulting from a combination of physical losses and non-physical losses on an appraisal object starting from Sta $0+000$ to Sta $4+200$ to 48 (forty eight) owners of land acquisition objects with 109 (one hundred and nine) parcels of land with an area of approximately 261,456 m2. The fair replacement value calculated is the value of land, building value, value of growing plants and other non-physical losses.

In conducting the assessment, KJPP MBPRU refers to laws and regulations and Land Acquisition Assessment Standards for Development for Public Interest, namely the SPI 306 Technical Guidelines for the Indonesian Assessment Standard Preparation Committee (KPSPI) of the Indonesian Professional Appraisal Society (MAPPI) and in accordance with Article 3 paragraph (10) and Article 4 paragraph (2) of the Minister of Finance Regulation Number: 101 / PMK.01 / 2014 dated 9 June 2014 concerning Public Appraisers. KJPP in assessing land compensation for development in the public interest must use the existing standards in the Indonesian Appraisal Code of Ethics and Indonesian Appraisal Standards (KEPI and SPI).

In an interview with M. Rofiud Rozak (Appraiser at KJPP MBPRU) stated that it is necessary to know that SPI 306 is not updated every year but is updated based on professional needs according to the latest issues developing in the assessment work. According to SPI 306, number 2.11 regarding the Assessment for the purposes of compensation includes :

1) Compensation for physical (material) loss of land and / or buildings and / or plants and / or other objects related to land.

2) Non-physical (immaterial) compensation consists of compensation for the loss of title to the land owner to be given in the form of money (premium), as well as other losses that can be calculated including transaction costs, interest (waiting period compensation), loss of remaining land, and other types of losses stated by the assignor in the work agreement.

As for the approaches and methods used by the Independent Appraiser from the Public Appraisal Service Office Muttaqin Bambang Purwanto Rozak Uswatun \& Rekan in conducting the assessment are :

a) Market approach

The market approach is used for the valuation of land, buildings and crops where this market approach produces an indication of value by comparing the assets valued with identical or comparable assets, where information on transaction prices or offers provides an indication of the value.

It can be explained that the results of the assessment and calculation of the compensation price for land affected by the Padang-Pekanbaru toll road construction project for the DukuSicincin road segment are the first by looking at the land value zone, designation and analysis of HBU (Highest and Best Use), namely the highest and best utilization. Then, from the comparative data found around the location, adjustments were made to the location, access, time, soil shape, topography, elevation, area, soil physical condition, and so on.

b) Cost approach

With the cost calculation method, the property value (land and buildings) is obtained by considering the land as vacant land, the land value is calculated using the market data approach, while the building value is calculated using the cost calculation method. The market value of the building is calculated by calculating the cost of new reproduction / new replacement $(\mathrm{RCN})$ of the building at the time of appraisal less depreciation. For plant assessment, the cost approach method is also used, the cost referred to here is the cost required 
for one type of plant, starting from seedlings, planting process, maintenance, to harvesting and also refers to the Plant Growth Decree issued by the Regent of Padang Pariaman.

c) Non-physical compensation includes compensation for losses on the release of rights from the land owner to be given in the form of money (premium) based on the provisions of the prevailing laws and regulations (SPI 306 number 5.22). This can be described as follows :

1) Premium, including : (1) potential loss of job, loss of business or loss of business, including change of profession ; (2) emotional loss (solatium) suffered by the owner due to having to move house as a result of land acquisition for public purposes.

2) Transaction costs, including : moving costs, tax or BPHTB expenses, and Notary \& PPAT expenses.

3) Compensation for the waiting period (interest) is an amount of funds that is calculated as a replacement for the time difference between the valuation date and the estimated date of compensation payment.

4) Loss of remaining land: decrease in land value due to taking part of land parcels.

5) Other physical losses: Premium for depreciation expense, for example a part of the building that was cut off due to land acquisition, so it requires repair costs to function properly.

After the assessment was carried out by the appraisal team, the total value of compensation for the land acquisition object was 109 (one hundred and nine) parcels / parcels of land amounting to IDR. 15,087,030,000, - (fifteen billion eighty-seven million and thirty thousand rupiah). ${ }^{39}$

Furthermore, KJPP MBPRU reports the results of the assessment of the amount of compensation and issues a resume of the results of the assessment with Number: 005-PEM / PNL-P / MBPRU-PDG / MRR / V / 2018 dated May 182018 which was submitted on May 212018 to the Chief Executive. Land Acquisition with Minutes of Appraisal Result Submission in accordance with attachment XII of the Regulation of the Head of the National Land Agency No. 5 of 2012 concerning Technical Guidelines for Land Acquisition Implementation.

\section{3) Deliberation}

The resume of the assessment results issued by the KJPP MBPRU is used as a basis or reference in determining the form of compensation for land acquisition at the time of the deliberation. The executor of land acquisition gave an invitation through a letter from the Ministry of Agrarian Affairs and Spatial Planning / National Land Agency, Padang Pariaman Regency Land Office, West Sumatra Province Number: 276 / 13.05 / X / 2018 dated May 23, 2018 to entitled parties to be able to attend the deliberation held in May 252018 and May 262018 in the Batang Anai Sub-district Office Hall to determine the form of compensation for land acquisition for the Padang-Sicincin toll road. ${ }^{40}$ In deliberations that are held directly and led by the Head of Land Acquisition Committee or an official appointed to determine the form of compensation, it is then that the results of the KJPP MBPRU study are submitted to the owner of the land acquisition object.

Deliberations are held between Land Acquisition Implementers and Entitled Parties and agencies requiring land, namely the Ministry of Public Works and Public Housing, represented by Toll Road Commitment Making Officials in accordance with the provisions in Article 68 to Article 73 of Perpres No. 71 of 2012 to determine the form of compensation based on the results of the assessment of compensation. The meaning of

\footnotetext{
${ }^{39}$ Interview with Mr. Rofiud, Appraiser from KJPP MBPRU.

${ }^{40}$ Interview with Mr. Allex Suvrianto, Head of Sub-Division for Facilitation of Government Land Procurement and Designation at BPN Padang Pariaman.
} 
deliberation contained in Law no. 2 of 2012 which states that deliberation is only to agree on the form and / or amount of compensation which is determined based on the results of the assessment of compensation conducted by an appraiser which is held and determined by the Head of Land Acquisition. ${ }^{41}$ The form of compensation to be agreed upon in the deliberation is in accordance with Article 36 of Law Number 2 of 2012 which states that "Compensation for damages can be given in the form of" :

a.Money;

b. Replacement land;

c.Resettlement;

d. Shareholding;

e.Another form agreed upon by both parties".

Based on Article 75 paragraph (1) Presidential Decree No. 71 of 2012 which states that in deliberations to determine the form of compensation, the Land Acquisition Implementer prioritizes the provision of compensation in the form of money. Furthermore, the results of the deliberation are stated in the minutes of the results of the deliberation on the determination of compensation with the Minutes of Agreement Number 01/2018 dated 25 May 2018 and Number : 02/2018 dated 26 May 2018. However, the deliberation failed to reach an agreement where all Eligible Parties (represent) Those who attended the meeting agreed not to accept or disagree with the results of the assessment of the amount of compensation by the Appraiser from the KJPP MBPRU who was deemed inappropriate and unfair in accordance with the principles of humanity, justice and welfare because it was very far below the fair replacement value and when compared to compensation losses that have occurred in other nearby locations, namely land acquisition for the 2018 Batang Anai flood control and land acquisition for the Duku-BIM railway line in 2013 are very different. Then they signed a letter of rejection of the amount of compensation.

Here the researcher concludes that the deliberation is carried out only to discuss the form of compensation in which the Land Acquisition Implementer prioritizes the provision of compensation in the form of money and informs the entitled parties about the results of the Appraiser's assessment of the compensation value per plot of land so that it closes the possibility of any negotiation or Bargaining the price or the amount of compensation for the land acquisition object. It is better if to obtain an agreement from the Entitled Party so that as far as possible the Land Acquisition Implementer shall pay attention to the wishes of the deliberation participants, in this case the Entitled Party, regarding the desired price for land, buildings and plants so that they participate in determining the amount of compensation. Judging from Van Dunne's will theory which states that by taking into account the wishes of each party in the deliberation for compensation between the Entitled Party and the agency requiring land, the will of the parties can meet and an agreement can be reached. If there is such a striking price difference in compensation, a middle course is taken by observing the principle of justice for its settlement.

\section{4) The process of determining compensation}

Based on the Decree of Appraisal Service Appraisal or Public Appraiser for Land Acquisition Activities for the Construction of the Padang-Lubuk Alung-Padang Panjang-Bukittinggi Toll Road, the Padang-Sicincin Section Sta $0+000$ to Sta $4+200$ with a land area of \pm 35 Ha, Number : 128 / KEP-13.05 / V / 2018 dated 9 May 2018 stipulated by the Head of the Padang Pariaman Regency Land Office, which in essence determines the amount of compensation made by the Appraiser. The appraiser at the KJPP MBPRU determined that the total cost of compensation for Sta $0+000$ to Sta $4+200$ was IDR. 15,087,030,000, - (fifteen billion eighty seven million thirty three thousand rupiah) for 109 (one hundred and nine) parcels / parcels of land.

41 See Article 37 paragraph (1) of Law no. 2 of 2012. 
In this study, the authors argue that the determination of the value of compensation is based on the results of the appraiser's assessment, namely the Public Appraisal Service Office Report Letter of Mutaqin Bambang Purwanto Rozak Uswatun dan Partners (MBPRU) Number: 005-PEM / PNL-P / MBPRU / PDG / MRR / V / 2018 dated 18 May 2018 regarding the Appraisal of Land Prices, Buildings and Plant Land Acquisition Plants for Public Interest. Agreeing or disagreeing with the Eligible Party in deliberations regarding the amount of compensation value does not affect the determination of the amount of the compensation value. In other words, if the Entitled Party refuses the determination of the amount of compensation, the Entitled Party can file an objection or lawsuit to the Pariaman District Court.

Associated with the principle of justice presented by Plato, that something will be beneficial if it is in accordance with goodness which is the substance of justice itself. Likewise with John Rawls's theory of justice where Rawls requires the principle of social justice which provides the widest possible freedom for everyone and is able to rearrange social and economic differences in order to provide the greatest benefit to the community affected by the land acquisition so as to provide benefits that are of a nature, reciprocal benefits for both the lucky and the most disadvantaged. This explains that sacrifices in the public interest are permissible, but it is not true that such sacrifices are asked for from people who are already disadvantaged in the community affected by the toll road construction.

By taking into account the impact that will arise in the future on the community who holds the rights to the land, the principle of justice must be used in order to create community welfare. However, this was not done by the Executor so that it gave the impression that the price fixing was carried out unilaterally which resulted in injustice to the Entitled Party. The Implementer should have considered the results of the Appraiser's assessment with the wishes of the owner of land rights so that the provision of compensation is a form of respect for Eligible Parties who have been willing to sacrifice and relinquish their rights to their land for the sake of public interest, and for that they are obliged to get fair compensation from the Government.

\section{Process for submitting objections to the determination of the form and / or amount of compensation at the Pariaman District Court}

Based on Article 38 paragraph (1) of Law Number 2 of 2012 concerning Land Acquisition for Public Interest which states that "in the event that there is no agreement regarding the form and / or amount of compensation, the entitled party can file an objection to the local District Court within 14 (fourteen) working days after Deliberation on the determination of compensation conducted by the land agency with the entitled parties based on the appraiser's assessment ". As a basis for how to file this objection is regulated in the Regulation of the Supreme Court of the Republic of Indonesia Number 3 of 2016 concerning Procedures for Submitting Objections and Custody of Compensation to the District Court in Land Acquisition for Development for Public Interest (hereinafter referred to as Perma No.3 of 2016).

In accordance with Article 4 of the Supreme Court Regulation No. 3/2016, it is stated that "objections can be submitted by: (a) entitled parties or their proxies who are present but reject the results of deliberations to determine compensation; and (b) entitled parties who are not present and do not give power of attorney who rejects the results of the deliberation on determining compensation ". Referring to the provisions of Article 5 Perma No. 3 of 2016 which states that "Objections as referred to in Article 3 shall be submitted no later than 14 (fourteen) days after the results of deliberations on determining compensation". Regarding the implementation of the deliberations carried out by the last Land Acquisition Committee on May 26, 2018, in the land acquisition of the Padang-Sicincin toll road, the objections raised on June 28, 2018 were still within the timeframe stipulated by the Law which is from the date of June 11, 2018 to June 20, 2018 is a joint leave. 
The requirements for filing an objection are submitted in writing in Indonesian to the Pariaman District Court which contains : ${ }^{42}$

a) The identity of the objector applicant (name, age, place of residence, and occupation), namely as many as 47 (forty seven) people in Nagari Kasang as holders of land rights through their attorney namely Advocates at the law office "Palito Law Firm" domiciled in Jl. Dr. M. Hatta No. 11 Kelurahan Pasar Ambacang, Kuranji District, Padang City.

b) The application for objection also contains the identity of the respondent, namely: (1) Name and domicile of the Provincial BPN Regional Office or Regency / Municipal Land Office; (2) Name and domicile of the Agency requiring land. In this matter as a party to the Respondent the objection is :

1) The Minister of Public Works and Public Housing cq. The Official for Making the Commitment for Land Acquisition for the Padang-Sicincin toll road of the Ministry of PUPR, having its address at Jalan Jati Number 19 Padang, as the agency requiring land as Respondent I;

2) Head of the National Land Agency cq. Head of West Sumatra National Land Agency Regional Office cq. The Head of the Land Office of Padang Pariaman Regency having his address at Parit Malintang, 2x11 Enam Lingkung sub district, Padang Pariaman Regency as the Chairperson of the Land Acquisition Implementing Body as Respondent II;

c) Complete and clear mention of the location of the construction;

d) The mention of the time and place of implementation as well as the Minutes of the results of the deliberation on the determination of compensation, in the event that the objection applicant has a document on the minutes of the deliberation on the determination of compensation;

e) The description on which the objection is based: The legal position of the Objection Petitioner as an Entitled Party, the explanation for the filing of the objection is still within a period of 14 (fourteen) days after the deliberation to determine compensation in the event that the Objection Petitioner has a document on the results of the deliberation on the determination of compensation, and The reasons for the objection state clearly the matters which in principle explain that the form and / or amount of compensation is detrimental to the Petitioner.

f) The main thing requested in the application:

1. Granted the objection of the objection applicant;

2. Determine the form and / or amount of compensation according to the demands of the objection applicant;

3. To punish the respondent with an objection to carry out the provision of compensation according to the demands of the objector applicant;

4. To sentence the respondent to object to paying the court fee.

The objection may also be accompanied in a digital format stored electronically on a compact disc or similar (harmonized) storage medium. After the Application is submitted, the Registrar conducts administrative research and checks the preliminary evidence against the objection Application and after completing and the Applicant has paid the court fee through the Bank, the Registrar records it by register number: 81 / P.SK.Pdt / 2018 / PN Pmn, then submitted to the judge to be tried. Objections were filed because they rejected the amount of compensation for the fair replacement value from the Appraiser which the Petitioner considered was very low when compared to the 2018 NPOP. Plants that are on the land of the Petitioner in the Nominative List issued by the Chief Executive of Land Acquisition (Respondent II) with the results of the resume of land acquisition assessment issued by the Independent Appraiser of KJPP MBPRU, causing uncertainty about the amount of compensation value that the Petitioners will receive and this is felt by the Petitioner as something that is far from fairness and justice.

\footnotetext{
${ }^{42}$ Article 6 of the Supreme Court Regulation Number 3 of 2016.
} 
The land acquisition committee has a tendency to use NJOP (Tax Object Sales Value) as a reference for compensation, while on the other hand, land owners tend to use market prices or buying and selling prices and even often demand compensation for 3 (three) or 4 (four) times more. The size of the NJOP is added to the expectation of other non-physical losses which they consider to be inclusive as compensation so that it is more difficult when land owners take a position like rent hunters. ${ }^{43}$ Residents who own the land are ready to surrender their land but ask the government that the price of land is valued appropriately or commensurately because a commensurate price can become business capital for them and the land is a productive area besides being a dense settlement it is also the center of economic activity for the Nagari Sicincin community.

Subsequently, the District Court decides the form and / or amount of compensation within a maximum period of 30 (thirty) working days from the receipt of the objection. For this reason, the Pariaman District Court issued Decision Number: 32 / Pdt.G / 2018 / PN-Pmn dated 31 July 2018 which stated that they rejected the Petitioners 'claim and stated that the applicants' objections were unacceptable or NO (Niet Ovankalijke Verklaard). According to Yahya Harahap, what is meant by "Decision NO (Niet Ovankalijke Verklaard)" is a decision stating that the Lawsuit is Unacceptable because it contains formal defects attached to the lawsuit, including : ${ }^{44}$

1.) A lawsuit signed based on a power of attorney that does not meet the requirements outlined in Article 123 paragraph (1) HIR in conjunction with Supreme Court Circular Letter Number 6 of 1994;

2.) The lawsuit has no legal basis;

3.) A lawsuit for error in person in the form of disqualification or plurium litis consortium;

4.) The claim contains defects in obscuur libel, ne bis in idem, or violates absolute or relative jurisdiction (competence).

In the Petition for Objection, the Petitioner stated that there were differences in the data on land area and plant contents in the Nominative List issued by Respondent II (Head of BPN cq. Head of West Sumatra BPN Regional Office cq. Head of Land Office of Padang Pariaman Regency) and incompatible compensation, not feasible, and unfair because it is very far below the fair replacement value stipulated by SPI 306, and in its petitum the Petitioner objected to asking the Judge to order the Respondents (PUPR Minister cq PPK Land Procurement and Head of BPN cq West Sumatra BPN Regional Office cq. Head of Land Office of Padang Pariaman Regency) to re-measure and re-register all objects of compensation. Whereas in its Consideration the Pariaman District Court Judge stated that there was a contradiction (mismatch) between the basis, purpose or reason for filing the petition (posita), namely "petition for an objection to compensation" and a petitum (demand) which asked the Panel of Judges to "order the Respondent to measure and re-record the all objects for compensation "where this has been proven by the improvement of the nominative list Number: 03/2018 dated May 92018 which was submitted at the deliberation to determine compensation on May 25, 2018, so that the Petitioners in the petitum should no longer ask the Panel of Judges to ordered the Respondents to measure and re-record all objects of compensation.

Whereas based on the description of Article 38 paragraph (1) of Law Number 2 of 2012 in conjunction with Article 73 paragraph (1) Presidential Regulation Number 71 of 2012 in conjunction with Article 2 of the Regulation of the Supreme Court Number 3 of 2016 which states "The court has the authority to examine, adjudicate, decide and resolve objections to the form and / or amount of compensation determined based on Deliberation on Determination of Compensation ". In connection with this, the object of objection is the form and / or amount of compensation for land acquisition not to re-

\footnotetext{
${ }^{43}$ Gunanegara, 2016, State Administration Law, Sale and Purchase and Land Acquisition, History of the Establishment of Indonesian Land Acquisition Law, Tatanusa, Cet. First, Jakarta, p. 14.

${ }^{44}$ M. Yahya Harahap, Op. Cit., p. 811.
} 
measure the land object as the Petitioners 'petitum, therefore resulting in the Petitioners' petition containing formal defects so that the petition is declared vague (obscuur libel) and objections are not acceptable. In this case the petitum which is not in line with the argument of the lawsuit contains an obscuur libel defect.

Then on the Pariaman District Court Decision, the Petitioner can make legal remedies, namely the appeal that is submitted to the Supreme Court no later than 14 (fourteen) days after the Court Decision was pronounced in court in accordance with Article 38 paragraph (3) of Law Number 2 of 2012 jo Article 73 paragraph (3) Presidential Regulation Number 71 of 2012 in conjunction with Article 21 paragraph (2) of the Supreme Court Regulation Number 3 of 2016. However, the Petitioners did not file an appeal for legal action and because there were no more objections from the entitled parties, the Decision it has permanent legal force (inkracht) and must be implemented by the parties. In the provisions of Article 23 of the Supreme Court Regulation Number 3 of 2016 states "The Cassation Decision is a final and binding decision for which no legal remedy for judicial review is available". Against Decision $N O$ in civil cases, a new lawsuit can still be filed after the Plaintiff has corrected his lawsuit.

From the description above it can be concluded that the law which aims to maintain public order and protect the interests of the community by implementing the rules stipulated by law through Judges' decisions with an attitude of legal independence and impartiality in applying legal rules to resolve disputes between parties so that there is consistency of legal certainty in filing an objection to compensation. In this case, the Entitled Party is deemed to have accepted the form and amount of compensation and the Court strengthens the determination of the amount of compensation as determined by the Land Acquisition Appraiser by stating that the petition for objection to compensation submitted by the Petitioners is unacceptable (Article 20 letter (d) Perma Number 3 of 2016).

\section{Implementation of Deposit for Compensation in Land Acquisition for the Construction of the Padang-Pekanbaru Toll Road on the Padang-Sic Cincin Road Section in Public Interest}

The implementation of deposit for compensation in land acquisition is carried out in accordance with the provisions stipulated in :

1.) Article 42 of Law Number 2 of 2012 which states:

Paragraph (1) "In the event that the Eligible Party refuses the form and / or amount of compensation based on the deliberation on the determination of the compensation based on the appraiser's assessment or based on the decision of the District Court / Supreme Court which has obtained permanent legal force against the objection submitted by the Eligible Party, then the compensation will be deposited at the local District Court".

Paragraph (2) "The deposit of compensation other than those referred to in paragraph (1) is also carried out for :

a. a. The whereabouts of the party entitled to receive compensation are unknown; or

b. b. The land acquisition object will be given compensation :

1. Being the object of a case in court;

2. Ownership is still disputed;

3. The authorized official has confiscated; or

4. Being a collateral at the bank.

2.) Article 86 - Article 95 Presidential Regulation Number 71 of 2012

Article 86 states :

(1) In the event that there is custody of compensation, the agency requiring land shall apply for custody of compensation to the Chairman of the District Court in the area where the construction site is for the public interest. 
(2) The custody of the compensation shall be submitted to the local District Court in the area where the construction is located for the public interest.

(3) The deposit of compensation as referred to in paragraph (2) shall be conducted in the event that :

a. The Entitled Party rejects the form and / or amount of compensation based on the results of the deliberation on Determination of Compensation but does not file an objection to the Court.

b. The Entitled Party to refuse the form and / or amount of compensation based on the Pariaman District Court Decision which has obtained permanent legal force;

c. The existence of the Eligible Party is unknown;

d. Land Acquisition Object that will be given compensation :

1) Being the object of a case in court;

2) Disputes over ownership of land rights;

3) The authorized official has confiscated;

4) Become collateral in the bank.

3.) Article 37 and Article 38 of the Regulation of the Head of the National Land Agency Number 5 of 2012

Article 37

(1) Deposit of compensation at the District Court as referred to in Article 86 to Article 95 of Presidential Decree Number 71 of 2012 concerning the Implementation of Land Acquisition for Development for Public Interest, carried out at the District Court in the Area of Land Acquisition for Development for Public Interest.

(2) Deposit of Compensation in accordance with the provisions in Article 86 paragraph (30 of Presidential Decree Number 71 of 2012 concerning Implementation of Land Acquisition for Development for Public Interest, is carried out in the event that:

a. The Entitled Party refuses the form and / or amount of compensation based on the results of deliberation and does not submit an objection to the District Court.

b. The Entitled Party rejects the form and / or amount of compensation based on the decision of the District Court / Supreme Court which has obtained permanent legal force;

c. The existence of the Eligible Party is unknown;

d. In the event that the Entitled Party has been properly invited does not attend and does not give power, as referred to in Article 71 paragraph (3) of Presidential Decree Number 71 of 2012 concerning Implementation of Land Acquisition for Development for Public Interest; or

e. Land Acquisition Object that will be given compensation :

1) Being the object of a case in court;

2) Ownership is still disputed;

3) The authorized official has confiscated; or

4) As collateral in a bank or other debt collateral.

(3) In the event that there is a deposit for compensation as referred to in paragraph (2), an Official Report shall be made in accordance with the Attachments in this Regulation..

4.) Article 24 - Article 35 of the Supreme Court Regulation Number 3 of 2016.

Article 24

(1) The agency requiring land may apply for Deposit of Compensation to the Court if it meets one or more of the following conditions: ${ }^{45}$

${ }^{45}$ Article 24 of the Supreme Court Regulation Number 3 of 2016. 
a. The Entitled Party rejects the form and / or amount of compensation based on the results of the deliberation on Determination of Compensation but does not file an objection to the Court.

b. The Entitled Party refuses the form and / or amount of compensation based on a court decision which has permanent legal force;

c. The existence of the Eligible Party is unknown;

d. Land Acquisition Object that will be given compensation :

1) Being the object of a case in court;

2) Ownership is still disputed;

3) The authorized official has confiscated;

4) Become collateral in the bank.

(2) (2) The form of compensation that can be deposited at the Court as referred to in paragraph (1) is in the form of currency in rupiah.

In the Padang-Pekanbaru Toll Road Project, the Padang-Sicincin Road Section Sta $0+000$ to Sta $4+200$ has been deposited with the Pariaman District Court due to :

1) The Entitled Party refuses the form and / or amount of compensation based on the deliberation on the Determination of Compensation but does not file an Objection to the Court.

2) The party entitled to refuse the form and / or amount of compensation based on the decision of the Pariaman District Court which has obtained permanent legal force;

3) The existence of the Eligible Party is unknown;

4) The land acquisition object that will be compensated is still in dispute over land rights.

Application for Deposit of Compensation is submitted by the agency requiring land, in this case the Ministry of Public Works and Public Housing, Directorate General of Highways, Directorate of Freeway, Urban and Regional Road Facilitation, Land Acquisition Unit for Region II Toll Road located at Jalan Jati No. 109 Padang, represented by Siska Martha Sari as Commitment Making Officer (PPK) for Land Acquisition of the Padang-Lubuk Alung-Padang Panjang-Bukittinggi Toll Road, the PadangSicincin Section based on the Decree of the Minister of Public Works and Public Housing Number: 157 / KPTS / M / 2018 February 26, 2018, hereinafter referred to as the Petitioner, shall submit a written application for Custody of Compensation on October 31, 2018.

The application contains: The identity of the applicant, the identity of the respondent, a description of which is the basis for the application, the things being requested to be determined, then the application is signed by the applicant and attached supporting documents. Supporting documents can be: ${ }^{46}$

a. Evidence relating to the identity of the Petitioner;

b. Photocopy of West Sumatra Governor's Decree concerning Stipulation of Land Acquisition Location for Toll Road Development;

c. Photocopy of the Revision of the Nominative List of Toll Road Land Acquisition that proves the Respondent as the Entitled Party for the Land Acquisition Object;

d. Photocopy of Report letter from KJPP MBPRU Appraiser concerning Value of Compensation;

e. Photocopy of Minutes of Agreement resulting from deliberations on Determination of Compensation;

f. Photocopy of a copy of the Court Decision which has permanent legal force;

g. Photocopy of the Respondent's refusal letter on the form and / or amount of compensation based on deliberation on the determination of compensation or a court decision that has permanent legal force, if any;

\footnotetext{
${ }^{46}$ Article 24 of the Supreme Court Regulation Number 3 of 2016.
} 
h. Photocopy of lawsuit document or statement from the Court Clerk if the object of land acquisition is in the process of dispute resolution in court;

i. A photocopy of the document of the decision to place confiscation on the object is confiscated by an authorized official.

j. Photocopy of bank certificate and mortgage certificate in case the object of land acquisition becomes collateral at the bank.

If the application documents for deposit of compensation are complete, the Registrar will provide a receipt after the Applicant has paid the down payment through the Bank. Then record it in the Consignment Register Book and submit it to the Chief Justice. In the event that the Petitioner revokes an Application that has been recorded in the Consignment Register Book but the application file has not been submitted to the Chair of the Court, the Registrar shall issue a deed of revocation of the application and notify the Applicant accompanied by the return of the application file.

In the Land Acquisition of the Padang-Pekanbaru toll road, the Padang-Sicincin road section, the Petitioner submitted an Application for Custody of Compensation which was registered on 31 October 2018 as many as 6 (six) Applications. From the Petitioners' Petition, there were 3 (three) applications that were granted, namely Case Number 3 / Pdt.P.Con / 2018 / PN.Pmn, Number 4 / Pdt.P.Con / 2018 / PN.Pmn, and Number 5 / Pdt.P.Con / 2018 / PN.Pmn with a total of 119 (one hundred and nineteen) Respondents while 3 (three) more cases Number 1 / Pdt.P.Con / 2018 / PN.Pmn, Number 2 / Pdt.P.Con / 2018 / PN.Pmn, and Number 6 / Pdt.P.Con / 2018 / PN.Pmn with a total of 9 (nine) Respondents were rejected by the judge because the Petitioners 'data submitted by the Petitioners did not match the Petitioners' Petition, therefore the Consignment Application submitted by the Petitioner could not be accepted $(N O)$. However, the petition can be submitted again to the Pariaman District Court after the Petitioner has corrected the petition.

Since the issuance of the Court's decision regarding the custody of compensation, there has been a termination of the legal relationship between the entitled party and the object of land acquisition, whose compensation has been deposited in the Pariaman District Court and because of that, the ownership or rights to land owned by the Entitled Party are abolished and evidence of their rights is declared invalid and the land becomes land directly controlled by the State. The total amount of money deposited at the Pariaman District Court is IDR. 18,663,292,650, - (eighteen billion six hundred sixty three million two hundred ninety-two thousand six hundred and fifty rupiah).

For the claim of compensation in this case : ${ }^{47}$

1) In the event that the party entitled to refuse the form and / or amount of compensation based on the Deliberation for Determination of Compensation but does not file an objection to the District Court or refuses compensation based on a court decision that has obtained permanent legal force, the compensation can be taken within a reasonable time. desired by the entitled party, accompanied by a cover letter from the Head of Land Acquisition Executive. ${ }^{48}$

2) As for Parties whose whereabouts are not known, the Land Acquisition Implementer delivers a notification regarding the existence of the entitled party in writing to the Head of Sub-district and Head of Village / Village Head, if its existence is known then the party entitled to submit a request to the Court to take compensation is accompanied by a letter introduction from the Chief Executive of Land Acquisition. ${ }^{49}$

3) For the object of land acquisition that is the object of a case at the Court or is still in dispute, compensation is taken by the entitled party at the court registry after receiving a court decision

\footnotetext{
${ }^{47}$ See Supreme Court Regulation Number 3 of 2016 Part Five concerning Withdrawal of Compensation Deposits

${ }^{48}$ See Article 30 of the Supreme Court Regulation Number 3 of 2016.

${ }^{49}$ See Article 31 of the Supreme Court Regulation Number 3 of 2016.
} 
that has permanent legal force or a peace deed accompanied by a cover letter from the Chief Executive of Land Acquisition. ${ }^{50}$

4) Next, in the event that the object of land acquisition is confiscated by the authorized official, the compensation shall be taken by the entitled party at the court clerk of the court after a court decision which has permanent legal force or has been confiscated accompanied by a cover letter from the head of the executor of land acquisition. ${ }^{51}$

5) Furthermore, for land acquisition objects that become collateral at the Bank, compensation can be taken at the court clerk after the approval of the Bank is accompanied by a cover letter from the Head of Land Acquisition Executive. ${ }^{52}$

For each withdrawal of Compensation to the Registrar's Office of the Pariaman District Court, the Eligible Party must bring a Letter of Introduction from the Head of Land Acquisition, in this case the Head of the Land Office of Padang Pariaman Regency and the Registrar must make an Official Report of Withdrawal of Deposit Compensation Fund signed by the Entitled and 2 (two) witnesses.

Furthermore, the results of the author's interview with the clerk of the Pariaman District Court, Mustofa, can be seen that the available funds or compensation deposits that have not been collected by the Entitled at the Registrar's Office are approximately IDR 17 billion (seventeen billion rupiah). Consignment money that has been deposited and deposited in the Registrar's Office of the Pariaman District Court where the money is combined in one account with other civil case money at Bank Syariah Mandiri Pariaman Branch.

The number of civil cases related to land disputes submitted to the Pariaman District Court, among others, are related to inheritance disputes, debts and debts with land as collateral, State Administrative Disputes regarding the issuance of land certificates, as well as other unlawful actions which cause the provision of compensation to entitled parties to be delayed because they have to wait for the completion of the court process until the case becomes in kracht or has permanent legal force, so the land acquisition committee keeps the compensation to the Pariaman District Court.

Furthermore, if the case has been resolved, the entitled parties can file compensation payments to the Court by first asking for approval from the land agency, in this case the BPN of Padang Pariaman Regency, then following the procedure set by the Court through the Supreme Court Regulation Number 3 of 2016. From the description above, it can be seen that legal certainty is needed in the process of land acquisition for the public interest where the determination of the Entitled Party to receive compensation to be given by the government is known after the legal process in court is completed.

\section{Conclusion}

1. The process of appraisal and determination of compensation in land acquisition for the construction of the Padang-Pekanbaru toll road on the Padang-Sicincin road section as a public interest is carried out starting from the appraisal team appointment process, the appraisal team's compensation assessment process, deliberation, and the compensation determination process . The appointment of the appraisal team is determined by the Chief Executive of Land Acquisition and the method of selecting the consultancy service provider is by direct procurement. The Appraiser makes an appraisal of the object of land acquisition using the Fair Replacement Value and refers to the standards in the Indonesian Appraisal Code of Ethics and the SPI 306 Technical Guidelines. The results of the Appraiser's assessment are used as the basis for deliberation to determine the value of compensation.

${ }^{50}$ See Article 32 of the Supreme Court Regulation Number 3 of 2016.

${ }^{51}$ See Article 33 of the Supreme Court Regulation Number 3 of 2016.

52 See Article 31 of the Supreme Court Regulation Number 3 of 2016. 
The fact is that the deliberations are carried out as they should, but the price set by the Appraiser (Appraisal) is as if it were only a final price that must be agreed upon by the Entitled Party, even though the price recommended by the Appraisal is a price that is the price for negotiating with the community land owner. So the unilateral price fixing without the participation of the people who own the land to determine the price, creates a sense of injustice for people who will give up and release their land, buildings or crops for the benefit of toll road construction. Like it or not, the community who owns land rights must accept the price set by the Appraisal.

2. The process for submitting objections to the determination of the form and / or amount of compensation at the Pariaman District Court is based on the Supreme Court Regulation Number 3 of 2016 concerning Procedures for Submitting Objections and Deposit of Compensation to the District Court in Land Acquisition for Development for Public Interest. Filing this objection is a form of legal protection for the owner of land rights to submit his objection to the determination of the form or amount of compensation for land, buildings and plants or non-physical losses suffered by the entitled party.

3. The implementation of deposit for compensation in land acquisition for toll road construction or consignment through the Pariaman District Court is due to an Entitled Party refusing the form and / or amount of compensation based on a District Court Decision that has obtained permanent legal force, a land ownership dispute, and the presence of an unknown address. This consignment does not mean negating the principle of legal certainty because in accordance with the principle of providing compensation, namely the parties receiving compensation are really the entitled parties, which has been known since the land acquisition process took place through a verification and identification mechanism to find out who is entitled and land acquisition objects where the results of the inventory and identification that contain the nominated list of entitled parties and the objects of land acquisition are the basis for determining the Entitled Party in granting compensation.

\section{Suggestion}

1. In land acquisition activities, the executor should be even more active in conducting studies from various points of view such as from a juridical point of view, namely the implementation or working mechanism of the land acquisition committee must be based on normative juridical starting from the Law, Presidential Decree, Ministerial Decree to the The governor's decision, in terms of sociology, is the impact of the construction of the toll road on the affected communities and victims of land acquisition, and the factors that hinder it so that solutions can be found, such as taking a more approach to reveal the root of the problem or problems that occur regarding why every land acquisition activity carried out by the government has experienced rejection from the community.

2. It is recommended that in determining the form and amount of compensation, the suggestions and considerations of both parties must be considered so that as far as possible, compensation is determined that approaches the fulfillment of a sense of justice for both parties so that it can be avoided to Proceed or Proceed in Court.

3. In the implementation of deliberations for the provision of compensation, as far as possible an agreement should be reached between the land agency and the community so that the compensation is received directly by the entitled party and there is no need for safekeeping to the District Court where the land acquisition was carried out. 


\section{Thank-You Note}

The author would like to thank all those who supported the writing of this article and give the highest appreciation to the Faculty of Law, Andalas University, Padang, Indonesia.

\section{Bibliography}

Abdul Kadir Muhammad, Law and Legal Research, Citra Aditya Bhakti, Bandung, 2004.

Adrian Sutedi, Transfer of Land Rights and Registration, Sinar Grafika, Jakarta, 2017.

Boedi Harsono, Indonesian Agrarian Law, History of the Formation of Basic Agrarian Laws, Content and Implementation, Volume I of National Land Law, Trisakti University, Jakarta, 2016.

C.S.T. Kansil, About Human Rights Today, Karya Unipres, Jakarta, 2003.

Djoni Sumardi Gozali, Land Acquisition Law, UII Press Yogyakarta, Yogyakarta, 2018.

E. Utrecht, Philipus M.Hadjon, in Hengki Andora's Dissertation, Land Control and Management by Government Agencies (Interaction of Land Law and State Financial Law in the Indonesian Legal System, Dissertation, Doctor of Law Program at Gadjah Mada University, 2019).

Gunanegara, State Administration Law, Sale and Purchase and Land Acquisition, History of the Establishment of Indonesian Land Acquisition Law, Tatanusa, Cet. First, Jakarta, 2016.

Lieke Lianadevi Tukgali, Social Function of Land Rights in Land Procurement for Public Interest, Kertasputih Communication, Jakarta, 2010.

Maria SW Sumardjono, State Authority to Regulate in the Concept of State Ownership of Land, Gajah Mada University Press, Yogyakarta, 1998.

Jakarta, 2008. , Land in the Perspective of Economic, Social and Cultural Rights, Kompas,

Mudakir Iskandar Syah, Land Acquisition for Public Interest Development, Permata Aksara,Jakarta, 2015. , Basics of Land Acquisition for Public Interest, Jala Permata, Jakarta, 2007.

Muhammad Fadli, Recognition of Customary Rights of Customary Law Communities in Land Procurement for Development on Former West Land Rights in West Sumatra, Thesis, Masters Program in Law at Andalas University, Padang, 2018.

Mustofa and Suratman, Use of Land Rights for Industry, Sinar Grafika, Jakarta, 2013.

Poppy Yulianti, Use of Consignment for Settlement of Compensation in Land Acquisition for Public Intlerest, Thesis, Master of Law Program, Andalas University, Padang, 2018.

Sudarsono, Legal Dictionary, Rineka Cipta, Jakarta, 2012.

Supriadi, Agrarian Law, Sinar Grafika, Jakarta, 2016.

\section{Laws and Regulations}

Law of the Republic of Indonesia Number 5 of 1960 concerning Basic Agrarian Regulations, State Gazette of the Republic of Indonesia of 1960 Number 104, Supplement to State Gazette of the Republic of Indonesia Number 2043.

Law Number 2 of 2012 concerning Land Acquisition for Development for Public Interest.

Presidential Regulation Number 71 of 2012 concerning Implementation of Land Acquisition for Development for Public Interest.

Presidential Regulation Number 148 of 2015 concerning the fourth Amendment to Presidential Regulation Number 71 of 2012 concerning Implementation of Land Acquisition for Development for Public Interest.

Presidential Regulation Number 3 of 2016 concerning Acceleration of National Strategic Project Implementation. 
Regulation of the Supreme Court of the Republic of Indonesia Number 3 of 2016 concerning Procedures for Submitting Objections and Custody of Compensation to the District Court in Land Acquisition for Development for Public Interest.

Regulation of the Head of the National Land Agency Number 5 of 2012 concerning Technical Guidelines for Land Acquisition as amended by Regulation of the Minister of Agrarian and Spatial Planning / Head of the National Land Agency Number 22 of 2015 concerning Second Amendment to the Regulation of the Head of the National Land Agency Number 5 of 2012 concerning Technical Guidelines for Implementation Land Acquisition

\section{Journal}

Sri Haryono et al, "The Position of Land Rights in Land Acquisition for Development for Public Interest (Analysis of the Substance of Law No.2 of 2012 concerning Land Acquisition for Development for Public Interest)", January-June 2016, Faculty of Law, UNS, in the Journal Repertorium Volume III Issue 1

\section{Internet}

Wikipedia; https://id.wikipedia.org/wiki/Jalan tol, accessed on 9 December 2019, 14.00 WIB.

CNN Indonesia; https://www.cnnindonesia.com/ekonomi/20190617201255-92-404045/pemerintahpastikan-tol-padang-pekanbaru-tetap-dibangun, accessed on December 10, 2019 at 14.00 WIB.

Negara Hukum, https://www.negarahukum.com/hukum/prinsip-prinsip-pengadaan-tanah-untukkepentingan-umum.html, accessed on 12 December 2019 at 06.00 WIB.

\section{Copyrights}

Copyright for this article is retained by the author(s), with first publication rights granted to the journal.

This is an open-access article distributed under the terms and conditions of the Creative Commons Attribution license (http://creativecommons.org/licenses/by/4.0/). 